\title{
Effects of Qat Water Extract Combined with Sublethal Dose of Cypermethrin on Fetuses Body Weight and Length of Pregnant Mice
}

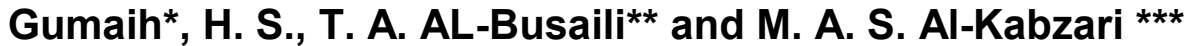 \\ * Associate Professor of Physiology, Biology Department, Faculty of Science, Sana'a \\ Univ., Yemen \\ ** Professor of Obstetrics and Gynecology Department, Faculty of Medicine and Health \\ Sciences, Sana'a University and Chairman of Obstetrics and Gynecology, Al-Sabain \\ Hospital, Republic of Yemen \\ ${ }^{* * *}$ Researcher at Agricultural Research and Extension Authority (AREA), Dhamar, \\ Yemen
}

\begin{abstract}
The effect of Qat water extract and sublethal concentration of Cypermethrin as active ingredient (A.I.) or formulated type (F) alone or in combination with Qat was evaluated on mice fetuses body weight and length. Female mice were exposed to these treatments during $6^{\text {th }}-18^{\text {th }}$ day of gestation. The results showed that there were significant reduction in mice fetuses body weight and length due to the administration of Qat extract alone, Cypermethrin alone, or the combinations of $5 \mathrm{~g} / \mathrm{kg}$ Qat extract with the respective sublethal dose of $1 / 10^{\text {th }} \mathrm{LD}_{50}$ $(25 \mathrm{mg} / \mathrm{kg}$ ) of either insecticide type. The formulated Cypermethrin (F) was more effective than its active ingredient type in all experiments, where the tested commercial formulation of Cypermethrin (Cymbush ${ }^{\circledR} 10 \%$ E.C.) showed a dramatic significant reduction in the fetuses body weight and length compared with the control. The reduction of body weight and length was higher in case of Qat extract $(5 \mathrm{~g} / \mathrm{kg})+1 / 10^{\text {th }} \mathrm{LD}_{50}$ of Cypermethrin formulation treatment with a mean reduction percentage of $40.00 \%$ of fetuses body weight and $59.31 \%$ of fetuses body length, while the mean reduction percentages for Cypermethrin (A.I.) were $36.24 \%$ and $51.91 \%$, respectively. Qat extract alone had a reduction percentage of $15.07 \%$ of fetuses body weight. It could be concluded that there is might be high a risk for those pregnant women who comsume Qat.
\end{abstract}

Keywords: Qat (Khat) extract, Cypermethrin, combinations, sublethal dose, fetuses body weight and length of the pregnant mice

\section{INTRODUCTION}

Qat, Catha edulis (Forssk.), is one of the widely freshly edible crops in Yemen and many African countries including Somalia, Kenya, Ethiopia, Djibouti, Madagascar, Tanzania and Uganda. The Qat plant top leaves and shoots are the main consumed parts for the habitual chewing of Qat and Qat is being used for centuries as a stimulant (Krikorian, 1984 and Kennedy, 1987). Low birth weight is a contributing risk factor in both prenatal and infant mortality among Qat chewers during pregnancy. Qat can affect fetal development during pregnancy via placental insufficiency, which could be explained by the extremely high blood pressure observed in these pregnant women (Dhaifalah and Santavy, 2004) and as a consequence, on fetal growth and development (El-Shoura et al., 1995 and Mwenda et al., 2003).

Pesticide products are composed of active and inert ingredients. The active ingredients are chemicals designed to kill, repel or suppress the pest. The inert ingredients are those added as solvents, emulsifiers and fillers to the pesticide product. The inert ingredients are defined as materials intentionally added to active ingredients during formulation of an end-use product to improve 
the physical characteristics of the commercial formulated pesticide. In fact, inert ingredients used in pesticides may have biological activity and some can be highly toxic (US EPA, 2012).

Due to the highly economic importance of Qat as a cash crop, its producers are always keen to use pesticides heavily for protection from various pests to ensure healthy Qat foliage for fresh consumption. It has been estimated that $70 \%$ of pesticides that are imported to Yemen used on Qat trees (Al-Gahashm and Mogaahed, 1988 and Apps et al., 2011). The unscientific and random use of pesticides, especially on Qat is one of the great dangers threatening human and environment in Yemen (Thabet, 1993). Moreover, there is a concern that people who consume Qat are at high risk of pesticide residues exposure. Residues of these pesticides and related toxic chemicals retard in adispose tissue are not kept inert, but are slowly released where they cause adverse health effects, immunological depression and mutagenic, teratogenic and carcinogenic effects (Thabet, 2002a). Studies conducted in Yemen indicated that some globally and nationally banned pesticides were still used on Qat trees. However, it has been reported that some banned and restricted pesticides are still available in pesticide retail shops and used by Yemeni Qat farmers. Chemical toxicity of pesticide residues is a serious problem in Qat production and may present immediate danger to the user if applied improperly or without sufficient knowledge of these toxic materials and their effects (Thabet, 2002b).

Qat causes various social, economic and health problems. Pesticides used in the developing countries still include many of the already banned or restricted insecticides such as Cypermethrin insecticide, which is banned in Yemen due to its cytotoxicity potential. Pesticides used on Qat trees in Yemen still include many of such banned or restricted ones. The possibility of foliage contamination with Cypermethrin residues is quite expected. The present investigation is devoted to investigate the effect of Qat water extract alone or comined with Cypermethrin insecticide as active ingredient or its commercial formulation on fetuses body weight and length of the pregnant mice as mammalian tested animal.

\section{MATERIALS AND METHODS}

\section{Tested Materials}

\section{Qat Plant Samples}

The fresh samples of stem tops and leaves of Qat, Catha edulis (Forsskal) were obtained from special farm located at Dulaa Hamdan, Sanaa Governorate, Yemen. The original Qat vegetation was kept away from any pesticides application.

\section{Pesticide Used}

Cypermethrin (98\% active ingredient) (Technical) (A.I) used in this study was obtained from Dimminico Ltd, Switzerland and the commercial formulation (Cymbush $^{\circledR} 10 \%$ E.C.) (F) was obtained from Syngenta, Basel, Switzerland. Acute oral toxicity $\left(L D_{50}\right)$ for mice $(250 \mathrm{mg} / \mathrm{kg})$ was taken in consideration according to US EPA (1989) and Ray (1991). 


\section{Treatment and Care of Animals Experimental Animals}

Male and female Swiss albino mice strain Mus musculus domestics were used for this study as they were ready for mating. They were obtained from Faculty of Agriculture, Sana'a University, Yemen. Virgin female and male mice were housed separately in plastic cages, each cage contained five female mice. Mice were fed on standard diet in plates containing protein, carbohydrates, fibers, vitamins and minerals (Aly, 2000). The animals were provided with tap water ad libitum and they were left for one week for adaptation under the laboratory environment before experimentation. Throughout the experimental period, care and cleaning were important for maintaining the animals in a normal healthy state. The experiment was carried out in the laboratory of Pesticides Chemistry, Plant Protection Department, Faculty of Agriculture, Sanaa University, Yemen.

\section{Animal Mating}

Two females (7- 8 weeks old) with an average weight of $30 \pm 2 \mathrm{~g}$ were provided with one sexually mature male of the same strain. They were placed in the cages at the appropriate time of estrus cycle. The presence of the sperms in the vaginal smear was considered as zero day of gestation. This procedure was carried out from 5 p.m to 9 a.m daily. Copulation was ascertained by the presence of a vaginal plug. The presence of a vaginal plug was counted as zero day of gestation (Brittebo et al., 1979; Anderson et al., 1989; Mark et al., 2001). Pregnant females were separated and housed in groups for treatment.

\section{Preparation of Qat Extract}

The fresh samples of stem tops and leaves of Qat, Catha edulis (Forssk.) were obtained from special farm (Dulaa Hamdan), Sanaa Governorate. The original Qat vegetation was kept away from any pesticide application. Qat stem tops and leaves were homogenized in distilled water (D.W.) using homogenizer for one hour. Then, the suspension was filtered through a Whatman No. 1 filter paper using a $5 \mathrm{~cm}$ diameter Buchner funnel. The crude extract of Qat was then transferred to a $50 \mathrm{ml}$ glass vial and stored as a stock solution at $-20^{\circ} \mathrm{C}$ until used.

\section{Experimental Design}

A standard volume of $0.5 \mathrm{ml}$ of Qat extract $(5 \mathrm{~g} / \mathrm{kg})$ alone or combined with another $0.5 \mathrm{ml}$ of $1 / 10^{\text {th }} \mathrm{LD}_{50}(25 \mathrm{mg} / \mathrm{kg})$ Cypermethrin insecticide active ingredient or its formulation were used to study their effect on body weight and length of fetuses of mice. Doses were calculated according to individual body weight on $6^{\text {th }}$ day of gestation. Studies involving short-term administration generally include exposing the pregnant female mice to the tested Qat extract alone or its combinations with both types of the tested insecticide during the period of organogenesis which is thought to be the period of maximum sensitivity to teratogenic agents (Tuchmann, 1965). The groups were treated from the day six of pregnancy and then every day until the $15^{\text {th }}$ day after gestation (total of 10 doses) as follows: 


\section{A: Control Groups}

Two control groups for each treatment were used; each group contained 5 pregnant females mice treated orally with the same volume of distilled water (as control for formulated [F] insecticide) or corn oil (for active ingredient [A.I.] insecticide).

\section{B: Treated Groups}

Group (1):15 pregnant female mice were treated with Qat extract alone or its combination with Cypermethrin active ingredient (A.I.) insecticide according to the following regimens:

Treatment 1 (T1): 5 pregnant female mice were treated with $0.5 \mathrm{ml}$ of the concentration of $5 \mathrm{~g} / \mathrm{kg}$ Qat extract alone.

Treatment 2 (T2): 5 pregnant female mice were treated with $1 / 10^{\text {th }} \operatorname{LD}_{50}$ (25 $\mathrm{mg} / \mathrm{kg}$ ) Cypermethrin (A.I.) insecticide alone.

Treatment 3 (T3): 5 pregnant female mice were treated with $5 \mathrm{~g} / \mathrm{kg}$ Qat extract + $1 / 10^{\text {th }}$ LD $_{50}(25 \mathrm{mg} / \mathrm{kg}$ ) Cypermethrin (A.I.) insecticide.

Group (2): 15 pregnant female mice were treated with Qat extract alone or its combination with Cypermethrin formulation ( $F$ ) insecticide according to the following regimens:

Treatment 1 (T1): 5 pregnant female mice treated with $5 \mathrm{~g} / \mathrm{kg}$ Qat extract alone. Treatment 2 (T2): 5 pregnant female mice treated with $1 / 10^{\text {th }} \mathrm{LD}_{50}(25 \mathrm{mg} / \mathrm{kg})$ Cypermethrin formulated insecticide $(F)$ alone.

Treatment 3 (T3): 5 pregnant female mice treated with the mixture of $5 \mathrm{~g} / \mathrm{kg}$ Qat extract $+1 / 10^{\text {th }} \mathrm{LD}_{50}(25 \mathrm{mg} / \mathrm{kg})$ Cypermethrin $(\mathrm{F})$ insecticide.

\section{Weights and Lengths of Fetuses}

Controls and treated pregnant female mice in each group were sacrificed 18 days of gestation by inhalation of ether. The abdominal skin was opened and the uterine horns were exteriorized through a midline abdominal incision. Each fetuses in right horn position (R.H.) and left horn position (L.H.) was removed from the uterus. Fetuses were examined for any external malformation, then the weight, length of fetuses body and reduction percentage of weight and length were recorded.

\section{Statistical Analysis}

Data were analyzed using IBM Statistic Package Version 21. All data are expressed as mean \pm standard deviation (SD) (Sendecor, 1987). Reduction percentage of weight and length were calculated as follows:

Reduction $\%=\frac{\text { Average of control }- \text { Average of treatment }}{\text { Average of control }} \mathrm{X} 100$

\section{RESULTS AND DISCUSSION}

\section{Effect of Qat water extract alone or in combination with Cypermethrin (A.I) on fetuses body weight and length}

The effect of the administration of either $5 \mathrm{~g} / \mathrm{kg}$ Qat extract alone, $1 / 10^{\text {th }}$ $\mathrm{LD}_{50}$ Cypermethrin (A.I.) insecticide alone or $5 \mathrm{~g} / \mathrm{kg}$ Qat extract combined with $1 / 10^{\text {th }} L_{50}$ Cypermethrin on the fetuses body weight and length is shown in 
Table (1) and Figure (1 and 2). The mean values ( \pm S.D.) of fetuses body weight resulted from the treatment of $5 \mathrm{~g} / \mathrm{kg}$ Qat extract alone were $1.52 \mathrm{~g}( \pm 0.03)$ with a reduction percentage of $14.12 \%$ in right horn $(\mathrm{R} . \mathrm{H})$ and $1.44 \mathrm{~g}( \pm 0.03)$ with reduction percentage of $14.29 \%$ in left horn $(\mathrm{L} . \mathrm{H})$. The recorded means $( \pm$ S.D.) for fetuses body length were $3.8 \pm 0.22 \mathrm{~cm}$ with a reduction of $3.55 \%$ in $\mathrm{R} . \mathrm{H}$ and $4.0 \pm 0.32 \mathrm{~cm}$ with a reduction percentage of $4.08 \%$ in $\mathrm{L} . \mathrm{H}$ for fetuses body length.

The mean of fetuses body weight resulted from the treatment of $1 / 10^{\text {th }}$ $\mathrm{LD}_{50}$ Cypermethrin (A.I.) insecticide alone was $1.29 \pm 0.12 \mathrm{~g}$ with a reduction percentage of $27.12 \%$ in $\mathrm{R} . \mathrm{H}$ and $1.23 \pm 0.12 \mathrm{~g}$ with a reduction percentage of $26.79 \%$ in L.H. Meanwhile, the recorded mean of the fetuses body length was $2.40 \pm 0.20 \mathrm{~cm}$ with a reduction percentage of $39.09 \%$ in R.H and $2.50 \pm 0.15 \mathrm{~cm}$ with a reduction percentage of $40.05 \%$ in L.H.

Table (1). Reduction percentages in fetuses body weight and length after treatment with Qat extract / Cypermethrin (A.I.) combinations during day $6^{\text {th }}$ to $18^{\text {th }}$ of gestation

\begin{tabular}{|c|c|c|c|c|}
\hline \multirow[t]{2}{*}{ Treatment } & \multicolumn{2}{|c|}{ Fetuses Body Weight (g) } & \multicolumn{2}{|c|}{ Fetuses Length (cm) } \\
\hline & R.H H $^{*}$ & L.H & R.H & L.H \\
\hline Control group & $1.77 \pm 0.04^{a^{* * *}}$ & $1.68 \pm 0.76^{a}$ & $3.94 \pm 0.15^{e}$ & $4.17 \pm 0.27^{e}$ \\
\hline $5 \mathrm{~g} / \mathrm{Kg}$ Qat Extract Alone & $1.52 \pm 0.03^{b}$ & $1.44 \pm 0.03^{b}$ & $3.80 \pm 0.22^{f}$ & $4.00 \pm 0.32^{f}$ \\
\hline Reduction \%** & \multirow{2}{*}{\multicolumn{2}{|c|}{14.21}} & 3.55 & 4.08 \\
\hline Mean of Reduction\% & & & \multicolumn{2}{|c|}{3.82} \\
\hline & R.H & L.H & R.H & L.H \\
\hline $\begin{array}{l}1 / 10^{\text {th }} L_{50} \text { Cypermethrin Alone } \\
\text { Reduction } \%\end{array}$ & $\begin{array}{l}1.29 \pm 0.12^{\mathrm{C}} \\
27.12\end{array}$ & $\begin{array}{l}1.23 \pm 0.12^{C} \\
26.79\end{array}$ & $\begin{array}{l}2.40 \pm 0.209 \\
39.09\end{array}$ & $\begin{array}{l}2.50 \pm 0.159 \\
40.05\end{array}$ \\
\hline Mean of Reduction \% & \multicolumn{2}{|c|}{26.96} & \multicolumn{2}{|c|}{39.57} \\
\hline & R.H & L.H & R.H & L.H \\
\hline $\begin{array}{l}5 \mathrm{~g} / \mathrm{Kg} \text { Qat Extract }+1 / 10^{\text {th }} \mathrm{LD}_{50} \\
\text { Cypermethrin }\end{array}$ & $1.13 \pm 0.06 \mathrm{~d}$ & $1.07 \pm 0.10^{d}$ & $1.90 \pm 0.16^{h}$ & $2.00 \pm 0.24 \mathrm{~h}$ \\
\hline Reduction $\%$ & 36.16 & 36.31 & 51.78 & 52.04 \\
\hline Mean of Reduction\% & \multicolumn{2}{|c|}{36.24} & \multicolumn{2}{|c|}{51.91} \\
\hline L.S.D. & 0.043 & 0.057 & 0.218 & 0.308 \\
\hline
\end{tabular}

(A.I.) $=$ Active Ingredient $\quad{ }^{*}$ R.H. = right horn position and L.H. = left horn position

** Reduction percentage as compared with control

*** $(M \pm$ S.D. $)=$ Mean of 5 replicates \pm Standard Deviation and these mean values having the same letter(s) are not significantly different from each other $(P<0.05)$.

L.S.D. = Least Significant Difference for treatment

The results proved that there was more reduction occurred in both weight and length of fetuses in the group which treated with $5 \mathrm{~g} / \mathrm{kg}$ Qat extract combined with $1 / 10^{\text {th }} L D_{50}$ Cypermethrin where the mean fetuses body weight were $1.13 \pm 0.06 \mathrm{~g}$ with a reduction percentage of $36.16 \%$ in $\mathrm{R} . \mathrm{H}$ and $1.07 \pm 0.10$ $\mathrm{g}$ with a reduction percentage of $36.31 \%$ in L.H.The means of fetuses body length were $1.90 \pm 0.16 \mathrm{~cm}$ (with reduction of $51.78 \%$ ) in R.H and $2.00 \pm 0.24 \mathrm{~cm}$ (with a reduction of $52.04 \%$ ) in L.H. Means of reduction percentages of fetuses body weight were $14.21 \%, 26.96 \%$ and $36.24 \%$ and the means of fetuses body length were $3.82 \%, 39.57 \%$ and $51.91 \%$ for the different running treatmens (5 g/kg Qat extract alone, $1 / 10^{\text {th }} L_{50}$ Cypermethrin alone and $5 \mathrm{~g} / \mathrm{kg}$ 
Qat extract combined with $1 / 10^{\text {th }} \mathrm{LD}_{50}$ Cypermethrin, respectively) as compared with the control treatment.

\section{Effect of Qat water extract in combination with Cypermethrin (F) on fetuses body weight and length}

Results in the Table (2) and Figure (1) clearly indicate that there were significant differences between the mean values of the fetuses body weight and length compared with the control as also photographed and illustrated in Plate 1.

The mean values of fetuses body weight due to the administration of 5 $\mathrm{g} / \mathrm{kg}$ Qat extract alone were $1.50 \pm 0.02 \mathrm{~g}$ giving a reduction percentage of $15.25 \%$ in R.H and $1.43 \pm 0.02 \mathrm{~g}$ (with $14.88 \%$ reduction) in L.H. Meanwhile, the means of fetuses body length were $3.80 \pm 0.16 \mathrm{~cm}$ (with $3.55 \%$ reduction) in R.H and $4.00 \pm 0.31 \mathrm{~cm}$ (with $4.08 \%$ reduction) in L.H.

Table (2). Reduction percentages in fetuses body weight and length after treatment with Qat extract/ Cypermethrin (F) combinations during day $6^{\text {th }}$ to $18^{\text {th }}$ of gestation

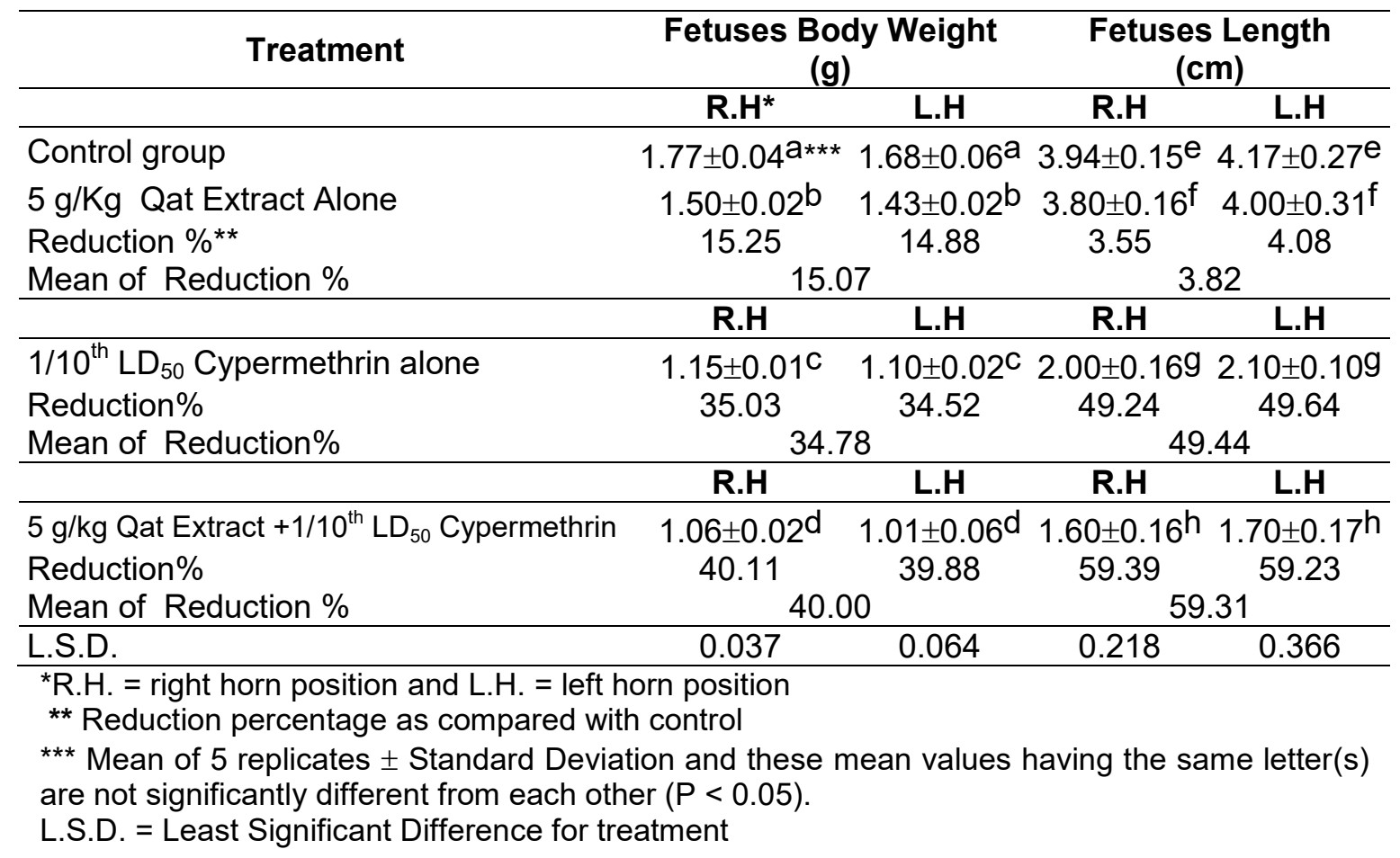

The estimated fetuses body weight means in treatment with Cypermethrin formulation insecticide $(F)$ alone $\left(1 / 10^{\text {th }} \quad L D_{50}\right)$ alone were $1.15 \pm 0.01 \mathrm{~g}$ with a reduction percentage of $35.03 \%$ in $\mathrm{R} . \mathrm{H}$ and $1.10 \pm 0.02 \mathrm{~g}$ with a reduction percentage of $34.52 \%$ for $\mathrm{L}$.H. The fetuses body length means were $2.00 \pm 0.16 \mathrm{~cm}$ (with reduction of $49.24 \%$ ) in R.H and $2.10 \pm 0.10 \mathrm{~cm}$ (with reduction of $49.64 \%$ ) in L.H. The results proved that there were more reduction in the body weight and length of fetuses especially in this group that has been treated with $5 \mathrm{~g} / \mathrm{kg}$ Qat extract combined with $1 / 10^{\text {th }} L_{50}$ of Cypermethrin (Cymbush ${ }^{\circledR} 10 \%$ E.C.). The fetuses body weight means were $1.06 \pm 0.02 \mathrm{~g}$ showing the highest reduction percentage of $40.11 \%$ in $\mathrm{R} . \mathrm{H}$ and $1.01 \pm 0.06 \mathrm{~g}$ 
with a higher reduction percentage of $39.88 \%$ in L.H. The means of fetuses body length were $1.60 \pm 0.16 \mathrm{~cm}$ showing the highest reduction $(59.39 \%)$ in R.H and $1.70 \pm 0.17 \mathrm{~cm}$ with a higher reduction (59.23\%) in L.H. Means of reduction percentages were $15.07 \%, 34.78 \%$ and $40 \%$ of fetuses body weight and $3.82 \%, 49.44 \%$ and $59.31 \%$ of fetuses body length in the following treatments: $5 \mathrm{~g} / \mathrm{Kg}$ Qat extract alone, $1 / 10^{\text {th }} L_{50}$ Cypermethrin (F.) alone and $5 \mathrm{~g} / \mathrm{Kg}$ Qat extract combined with $1 / 10^{\text {th }} L_{50}$ Cypermethrin ( $F$.), respectively as compared with the control. Cyprermethrin formulation was more effective than the active ingredient insecticide in all experiments where Cypermethrin formulation showd a dramatic significant reduction in the fetuses body weight and length compared with the control. Our results are in line with those reported by El-Sebae et al. (1978) who found that the formulated insecticides were higher in their mammalian toxicity than the corresponding technical materials. Also, El-Tawil and Marzouk (2015) concluded that the acute toxicities of these commercial pesticide formulations seemed to be more toxic than their reported toxicities which based on active ingredients.

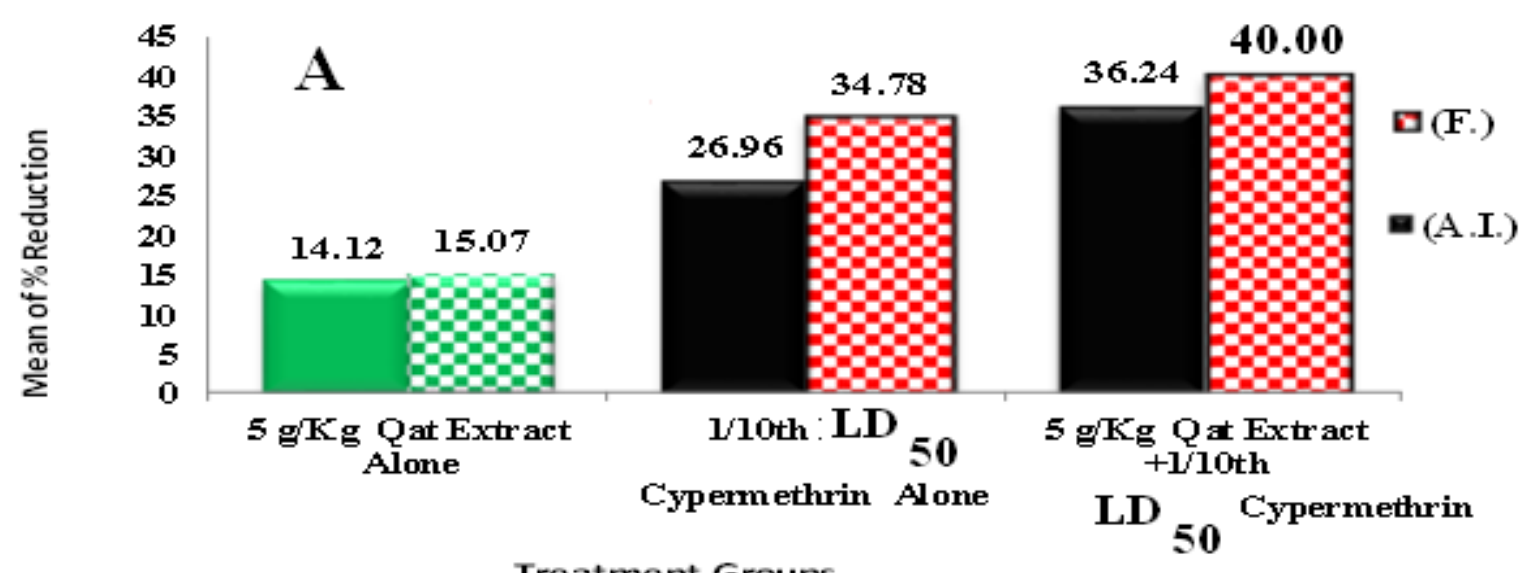

Treatment Groups

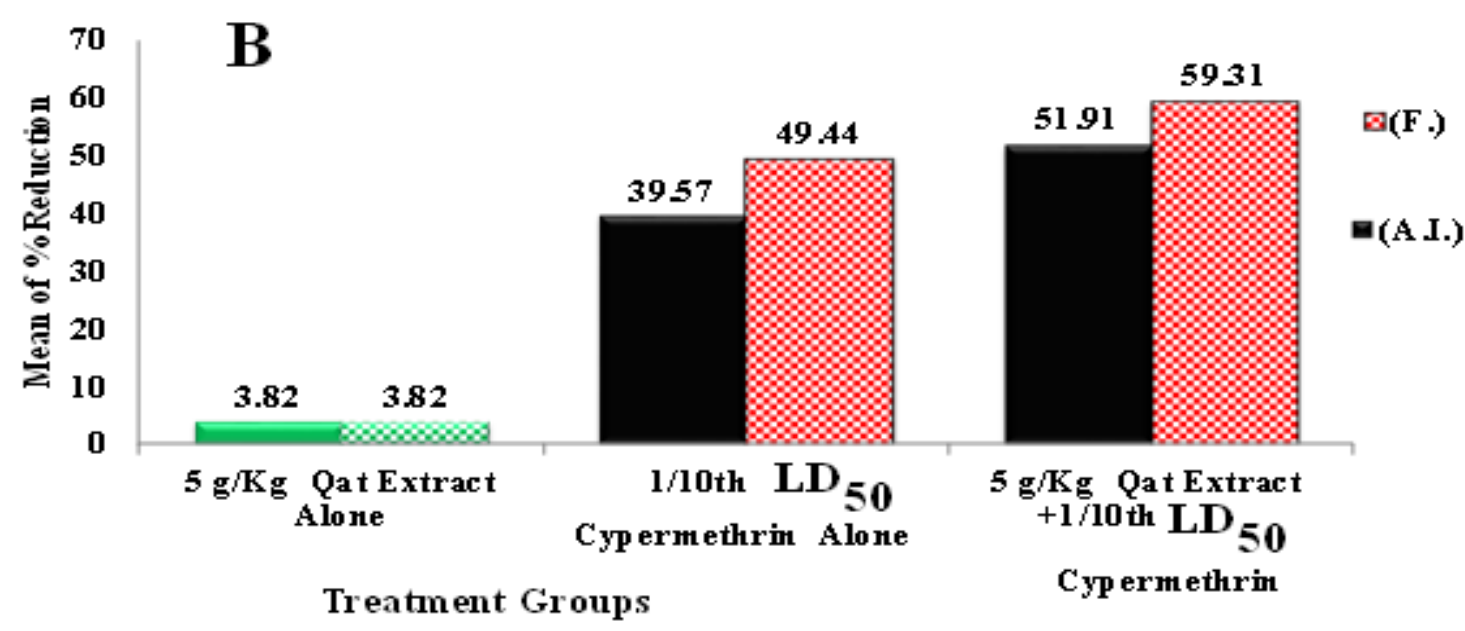

Figure (1). $A=$ mean reduction $\%$ of fetuses body weight after treatment with Qat extract/ Cypermethrin combinations from $6^{\text {th }}$ to $18^{\text {th }}$ Days of Gestation and B= mean reduction\% of fetuses body length after treatment with Qat extract/ Cypermethrin combinations from $6^{\text {th }}$ to $18^{\text {th }}$ day of gestation. 


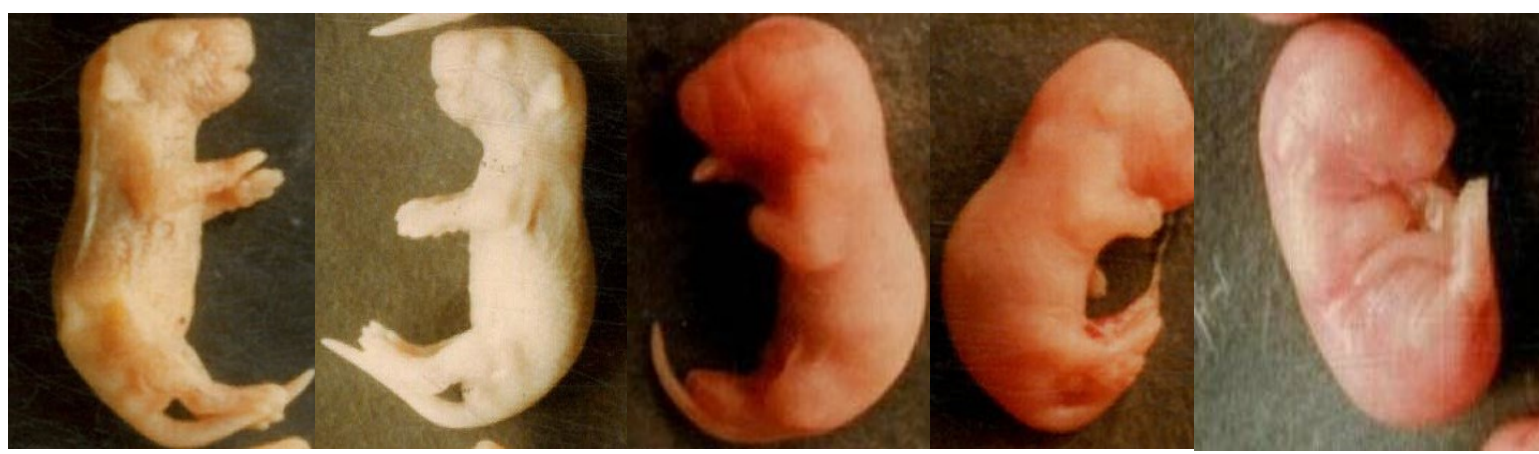

$\begin{array}{ccccc}\text { Photo (1): } & \text { Photo (2): Corn } & \text { Photo (3): } 5 \mathrm{~g} / \mathrm{kg} & \text { Photo }(4): & \text { Photo }(5): 5 \mathrm{~g} / \mathrm{kg} \\ \text { Distilled Water } & \text { Oil (Control) } & \text { Qat extract } & 1 / 10^{\text {th }} L D_{50} \text { of } & \text { Qat extract }+ \\ \text { (Control) } & & \text { alone. } & \text { Cymbush }^{\circledR}(10 & 1 / 10^{\text {th }} L D_{50} \\ & & & \% \text { EC) alone } & \text { Cymbush }^{\circledR}(10 \%\end{array}$

$\mathrm{EC})$

\section{Plate (1). Variations of fetuses obtained from the pregnant mice treated with distilled water or corn oil (control) and the different adminstrated treatmnents during Day $6^{\text {th }}$ to $18^{\text {th }}$ of gestation}

Photos (1 and 2): Body weight in fetuses from pregnant mice treated with distilled water or corn oil during day 6 to $18^{\text {th }}$ of Gestation, Photo (3): Loss in body weight in fetuses from mice treated with $5 \mathrm{~g} / \mathrm{Kg}$ Qat extract alone during day 6 to $18^{\text {th }}$ of Gestation and Photo (4): Loss in body weight in fetuses from mice after treated with $1 / 10^{\text {th }} L D_{50}$ Cypermethrin $(F$.$) alone and Photo$ (5): $5 \mathrm{~g} / \mathrm{kg}$ Qat extract $+1 / 10^{\text {th }} \mathrm{LD}_{50}$ Cypermethrin ( $F$.) during day 6 to $18^{\text {th }}$ of gestation.

The present study in mice was not preceded in the literature and it could be designed for the first time to examine the effects of Cypermethrin active ingredients and its commercial formulation on fetuses body weight and length of the pregnant mice during day 6-18 of gestation. Herein, Cypermethrin was applied as formulated products that contain the active ingredient, which has the killing power, and other ingredients that usually called inert ingredients, or inerts; these inerts have a variety of functions such as preventing caking or foaming, extending product shelf-life, helping the product stick to the surface of leaves and soil, spread over surfaces, allowing herbicides to penetrate plants, preventing clogging during application or making ingredients compatible (NPIC, 2011).

Knowing that the levels tested in our study of Qat resembles the low level of normal consumption and that the type and level of insecticide residues are already found in reality in the treated Qat fields in Yemen, then the adverse effects obtained in the teratogenic study should be used as alarming, especially to those pregnant mothers. Unfortunatly, for pregnant women, Qat consumption may have detrimental effects on uteri-placental blood flow and as a consequence, on fetal growth and development (Mwenda et al., 2003). Lower mean birth weight have also been reported in Qat chewing mothers compared to non-chewing Qat mothers, indicating an association between Qat chewing and decreased birth weight (Abdulghani et al., 1987 and Dalu, 2000). During pregnancy, Qat chewing is committing oneself to be one of the factors contributing to infant mortality. Qat is commonly chewed as well as Qat consumption affects the potency of male sexuality by affecting spermatogenesis 
and plasma testosterone concentration (Abderrahman and Modallal, 2008). Qat (extract or whole) showed increased locomotors activity and reduced weight in rats (Maitai, 1977). In pregnant rats, Qat reduces food consumption and maternal weight and also it lowers the food efficiency index (Islam et al., 1994).

Al-Bekairi et al. (1991) found that the treatment of mice with aqueous solution of cathinone at a dose of 5,20 and $40 \mathrm{mg} / \mathrm{kg}$ over a period of six weeks produced site specific soft lesions in the axilla, chest, cervical and abdominal regions. Cathinone also produced a lopecia and inflammation around the circumference of eye leading to the formulation of abscess and closure of eye. Khat (Qat) affects pregnant women by reducing maternal daily food intake and mean birth weight of the off spring (Jansson et al., 1988).

No differences in the rates of stillborns or congenital malformations were observed (Eriksson et al., 1991 and Vijaibasker, 2013). Qat is also known to be excreted in breast milk, but no studies have been conducted so far on how this affects nursing babies (Al-Mugahed, 2008). In pregnant women, Qat consumption may have detrimental effects on utero-placental blood flow and as a consequence, impacts fetal growth and development (El-Shoura et al., 1995). Qat affects pregnant women via reduction of their daily food intake; subsequently they give birth to malnourished infants (Al-Hegami, 2001 and Jansson et al., 1988). Low birth weight is a contributing risk factor in both prenatal and infant mortality among Qat chewers during pregnancy. Qat can affect fetal development during pregnancy via placental insufficiency, which could be explained by the extremely high blood pressure observed in these women (Dhaifalah and Santavy, 2004). Lower mean birth weights have been reported in Qat-chewing mothers compared to non-using mothers indicating an association between Qat chewing and decreased birth weight (Cox and Rampes, 2003).

The mean of percentage reduction was (15.07\%) for fetuses body weight. Lower mean birth weights have been reported in Qat -chewing mothers compared to non-using mothers indicating an association between Qat chewing and decreased birth weight (Cox and Rampes, 2003). Tariq et al. (1987) found that the methanolic Qat extract at doses of 250 and $500 \mathrm{mg} / \mathrm{kg}$ in female rats and significantly decrease the weight and length of fetuses delivered by rats treated with the extract. Savithri et al. (2014) observed a significant reduction in fetuses body weight and length and fetuses skeletal of pregnant mice due to sodium fluoride and Cypermethrin individual and combination treatments.

The present results may be considered as an important one to estimate gestational risk associated with insecticide exposure. In the light of the obtained results, Cypermethrin insecticides should not be used on Qat trees with caution to women who chew Qat during pregnancy. Moreover, a public awareness especially between youngsters must be announced to avoid the fatal habit and risk of Qat chewing. Therefore, this would be the responsibility of the health officers, educators, the media and growers to revise their philosophy and to implement a new policy in which Qat is no longer encouraged as an acceptable social habit in Republic of Yemen. 


\section{REFERENCES}

Abderrahman, S. M. and N. Modallal (2008). Genotoxic effects of Catha edulis (Khat) extract on mice bone marrow cells. J. Biol. Sci., 1(4):165-172.

Abdulghani, N. A., M. Eriksson, B. Kristiansson and A. Qirbi (1987). The influence of Khat-chewing on birth-weight in full-term infants. Soc. Sci. Med., 24(7): 625-627.

Al-Bekairi, M. A., F. S. Abulaban, S. Qureshi and A. H. Shah (1991). The toxicity of Catha edulis (Khat). A review. Fitoterapia, 62: 291-300.

Al-Gahashm, M. Y. and A. A. Mogaahed (1988). Pesticides on Qat; A danger threatens the society health: Dirasat Yamaniyyah. J. Yem. Cent. Stud. Res. Sana'a, Yemen Republic, 32.

Al-Hegami, M. (2001). Effects of Catha edulis on some blood contents and the tissues of the digestive system of rabbits. M.Sc. Thesis, Faculty of Science, Sana'a Univ., Yemen.

Al-Mugahed, L. (2008). Khat chewing in Yemen: Turning over a new leaf. Bull. World Health Organization, 86(10):741-742.

Aly, M. T. M. (2000). Effect of some rodenticides, adjuvants and their combinations on ceratin species of common mice and rats in Egypt. Ph.D Thesis, Faculty of Agric. (Saba Basha), Alex. Univ., Egypt.

Anderson, L. M., A. Hagiwara, R. M. Kovatch, S. Rehm and J. M. Rice (1989).Transplacental initiation of liver, lung, neurogenic and connective tissue tumors by $\mathrm{N}-\mathrm{Nitroso}$ compound in mice. Fund. Appl. Toxicol., 12(3): 604- 620.

Apps, A., S. Matloob, M. T. Dahdal and S.W. Dubrey (2011). Khat: An emerging threat to the heart in the UK. Postgrad. Med. J., 87:387-388.

Brittebo, E. B., A. Lindgren and H. Tjalve (1979). Studies on the distribution and metabolism of $\mathrm{C}^{14}$-dimethynitrosoamine in fetal and young mice. Acta pharmacol. Toxicol., 45:73-80.

Cox, G. and H. Rampes (2003). Adverse effects of khat: A review, Adv Psychiatr Treatm., 9:456-463.

Dalu, A. (2000). The impact of long term consumption of Khat on public health. Sidama Concern. 5(4):15-16.

Dhaifalah, I. and J. Santavy (2004). Khat habit and its health effect. A natural amphetamine. Biomed. Papers, 148(1):11-15.

El-Sebae, A. H., N. S. Ahmed and S.A. Soliman (1978). Effect of preexposure on acute toxicity of organophosphorus insecticides to white mice. J. Env. Sci. Health B,13(1): 4-24.

El-Shoura, S. M., M. Abdel-Aziz, M. E. Ali, M. M. El Said, K. Z. Ali, M. A. Kemeir, A. M. Raoof, M. Allam and E. M. Elmalik (1995). Deleterious effects of Khat addiction on semen parameters and sperm ultrastructure. Hum. Repord., 10 (9): 2295-2300.

El-Tawil, M. F. and E. M. A. Marzouk (2015). Acute oral toxicities of three pesticides used in Egyptian rice farms to albino rats. Current Sci. Int., 4(2):145-154.

Eriksson, M., N. A. Ghani and B. Kristiansson (1991). Khat chewing during pregnancy effect upon the off-spring and some characteristics of the chewers. East African Med. J., 68: 106-111. 
Islam, M.W., O. A. Al-Shabanah, M. M. Al-Harbi and N. M. Al-Gharably (1994). Evaluation of teratogenic potential of Khat, (Catha edulis Forsk.) in rats. Drug Chem. Toxicol., 17: 51- 68.

Jansson, T., B. Kristiansson and A. A. Al-Qirbi (1988). Effects of khat on maternal food intake, maternal weight gain and fetal growth in the late pregnant guinea pig. J. Ethnopharmacol, 23(1):11- 17.

Kennedy, J. G. (1987). The institutionalized use of the drug (Qat) in north Yemen. The botany, chemistry and pharmacology of Khat. In: The flower of paradise. Dordrecht and Boston, Kluwer/Reidel, Chapter 7, pp.176188.

Krikorian, A. D. (1984). Khat and its use: an historical perspective. J Ethnopharmacol., 12(2):115 -178.

Maitai, C. (1977). The toxicity of the plant Catha edulis in rats. Toxicon., 15:363-366.

Mark, A. S., D. V. M. P. Danneman and D.V. M. C. Brayton (2001). The Laboratory mouse. A volume in the laboratory animal pocket reference series. CRC Press. Boca Raton London New York Washington, D.C. 3840.

Mwenda, J. M., M. M. Arimi, M. C. Kyama and D. K. Langat (2003). Effects of khat (Catha edulis) consumption on reproductive function: a review, East Afr. Med. J., 80:318-323.

NPIC (2011). Inert or "other Ingredients". National Pesticides Information Center, Oregon State University. http://npic.orst.edu/factsheets/ inerts.pdf.

Ray, D. E. (1991). Pesticides derived from plants and other organisms. In: Handbook of Pesticide Toxicology. Hayes Jr. Wayland and Edward R. Laws, Jr. (Eds.). Academic Press, Inc. New York, NY, USA.

Savithri, Y., S. Ravi, P. S. Sravanthi and R. K. Jayantha (2014). Teratogenic effects of sodium fluoride and cypermethrin synergism in albino mice. Int. J. Chem. Pharmaceut. Sci. Mar., 5 (1):16- 67.

Sendecor, G. W. (1987). Statistical Methods $6^{\text {th }}$ edition. lowa State Univ. Press.

Tariq, M., N. S. Parmar, M. W. Islam, F. S. Feraly and I. A. Al-Meshal (1987). Hypercoagulable state-induced by Khat, Catha edulis (Forsk.) alkaloids and their enantiomers in normal Wistar albino rats. Res. Commun. Subst. Abuse., 8:29-38.

Thabet, A. A. M. (1993). Interaction between the extract of a natural plant and toxicology of some insecticides. Ph.D. Thesis, Pesticides Chemistry and Toxicology, Faculty of Agric., Alexandria Univ., El-Chatby, Alexandria, Egypt. Results presented in the Congress of Toxicology in Developing Countries, Cairo, Egypt. November 19-23, 1995. "In vivo neurological and biochemical effects of Qat, (Catha edulis) extracts in mice".

Thabet, A. A. M. (2002a). Qat: The existence exceeding the limit. 472 Pigs ministry of defense - Moral guidance department. Sana'a-Yemen.

Thabet, A. A. M. (2002b). Qat, Catha edulis (Forskal) and the environment. Proceeding of the Yemen national Qat conference. Ministry of planning and development. Sana"a. Yemen.1:14-28.

Tuchmann- Duplessis, H. (1965). Design and interpretation of teratogenic tests. In: Symposium on Embryopathic Activity of Drugs. J. M. Robertson, M. F. Sullivan and R.L. Smith (eds.) pp 56-87, Churchill, Londdon, UK. 
US EPA (1989). Pesticide fact sheet No. 199: Cypermethrin. Office of Pesticides and Toxic Substances, Washington DC, USA, pp. 2-9.

US EPA (2012). Inert ingredients in pesticide products. United States Environmental Protection Agency. Administrator United States environmental protection agency office of pesticide programs. Washington DC, USA, 20460.

Vijaibasker, G. (2013). A review on hazards of khat chewing. Int. J. Pharmacy Pharmaceut. Sci., 5 (3):74-77.

\title{
الملخص العربي
}

\section{ثأثير مستخلص القات المائي مع الجرعة تحث المميتة لمبيد السيبرمثرين على أوزان وأطوال أجنة القئران}

\author{
حسين صالح جميح" ، توفيق عبد الرب البصيلي ", منى احمد سعد الكبزري" "*"

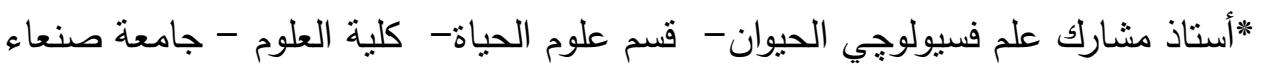 \\ **أستاذ أمراض النساء والتوليد - كلية الطب/ جامعة صنعاء- رئيس قسم النساء والتوليد بمستشفى فئس \\ السبعين \\ ***ب*ثة بالهيئة العامة للبحوث والإرشاد الزراعي - ذمار - الجمهورية اليمنية
}

تم دراسة تأثثر المستخلص المائي للقات والمبيد الحشري سيبرمثرين في صورة مادة فعالة وصورة مجهزة تجارية على أوزان وأطوال أجنة الفئران من اليوم السادس إلى اليوم الثامن عشر من الحمل ، وقد وجد أن أقل تأثنر علي فئي

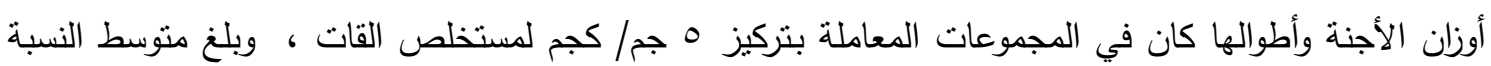

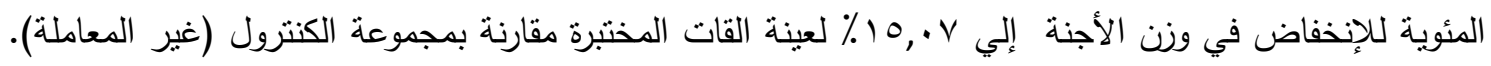

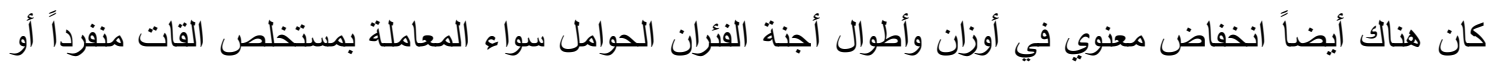

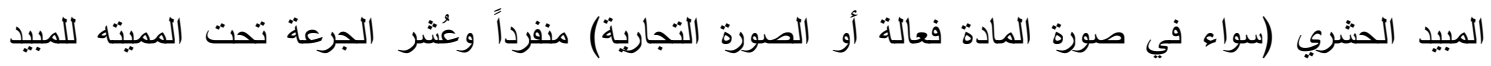
الحشري السيبرمثرين مخلوطاً مع نركيز ه جم/ كجم لمستخلص القات. وأظهر مبيد سيبرمثرين في صورته

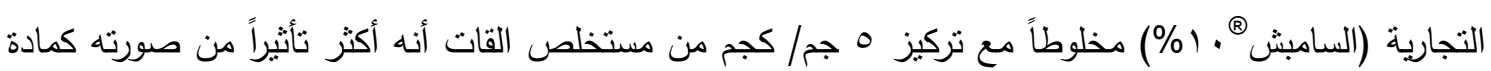

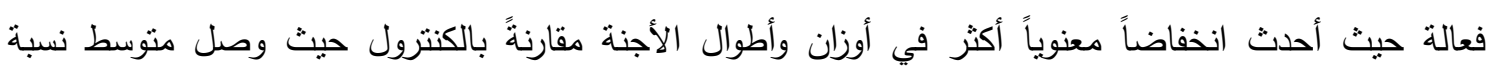

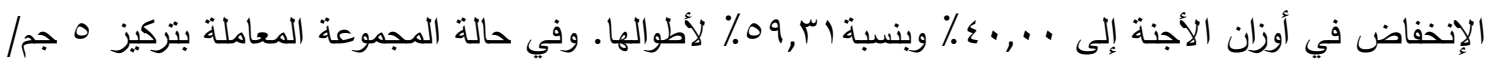

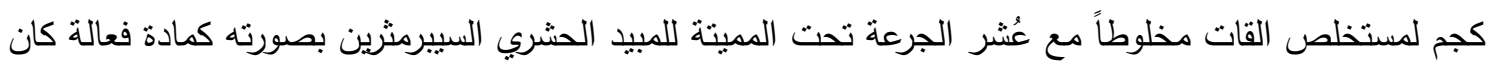

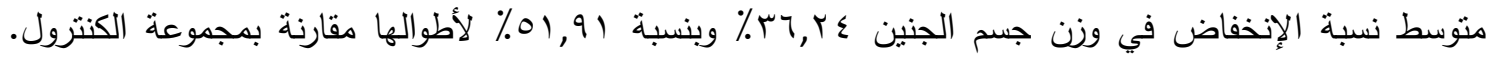
وعلي هذا فإن هذه الدراسة تثبر إلي تجنب إستهالك القات عن طريق الأمهات الحوامل حرصاً علي سلامة الأجنة وذللك من خلال التوعية الصحية. 